\title{
NATIONAL MINORITIES: A CASE STUDDY IN INTERNATIONAL PROTECTION
}

\author{
Mary Gardiner Jones*
}

\section{INTRODUCTION}

Characteristic of twentieth century society is its increasing emphasis on the group as a means for the individual to realize many of his basic aims and desires. ${ }^{1}$ As one authority has pointed out, "the scale of a modern society, the mobility, the range of communications, the variety of interests, the necessities of specializationall these combine to make any modern society ... multi-group society."2 The same author has emphasized the necessity for achieving a decent ordering of those intergroup relations if democracy is to flourish. A special aspect of this problem is presented by those groups which are formed not by reason of the special economic, social, or political interests of their members but rather by virtue of the similarity of their members with respect to race, language, or religion. The problem of the relationship of such "national minorities" to the majority is complicated by the fact of their frequent identification either in their own minds or in the minds of the majority with another political state which may represent a different cultural pattern, different traditions, and in some cases wholly different principles and values. Thus the factors involved in a harmonious adjustment of these intergroup relations are peculiarly international in nature and have accordingly given rise to demands for an international solution.

While both the Hungarian ${ }^{3}$ and the proposed Austrian ${ }^{4}$ peace treaties as well as

- B.A. 1943, Wellesley College; LL.B. 1948, Yale University. Member of the New York bar.

'A moment's reflection will conjure up countless groups with which an individual associates himself in order to accomplish certain ends. Labor unions, employers' associations, lobbies, Masons, Rotaries, women's and professional groups, literary and musical clubs, represent only a few which could be listed. One evidence of the importance of such group activity can be seen in the persecution of Free Mason groups in Germany and France by Hitler and his henchmen during World War II, and in the present attempts by the eastern European regimes to break down the dominance of the Roman Catholic Church. To destroy the group is to vitiate the effectiveness of the individual member. See in this connection, Maciver, Summation in Group Rezations aNd Group ANThgonisms 215, 222 (1944); and Cole, Europe's Conflict of Cultures, id. at I21.

${ }^{2}$ Maclver, Group Images and Group Realities in Group Rezamons and Group ANTAgonisms 3, 6 (I944).

All the peace treaties concluded with Italy, Bulgaria, Hungary, Rumania, and Finiand contain provisions obligating these countries to secure to all inhabitants the enjoyment of human rights and fundamental freedoms. Italy: Art. 15; Bulgaria: Art. 2; Hungary: Art. 2; Rumania: Art. 3; Finland: Art. 6. (Dep't State Pub. 2743, Eur. Ser. 2I (I947)). In addition, provisions with respect to nationality and option rights are contained in the Italian peace treaty (Arts. I9 and 20). Only the Hungarian treaty, however, contains any specific reference to minorities. In Article 5 of this treaty, Hungary has obligated herself to negotiate with Czechoslovakia for the solution of the problem of inhabitants of Magyar ethnic origin residing in Czechoslovakia.

According to reports, agreement has been reached on the rights and privileges to be enjoyed by the Slovene and Croat minorities in Austria. These rights include: (I) equality of treatment between 
certain national constitutions, ${ }^{5}$ contain some provision for the protection of minority rights, countless minority groups throughout the world remain without legal protection of any kind. Considerable progress has been achieved by the United Nations in securing certain basic rights to every individual regardless of race, color, creed, or nationality, ${ }^{6}$ but the formulation of a similar charter for the protection of group rights-or as they are more popularly referred to, minority rights-has made little progress. ${ }^{7}$

One major source of difficulty arises from the complexities of the group types which might form the object of protection, and from the unwillingness of states to accord legal recognition to what they regard as external interference with their domestic affairs. Another stems from a lack of conviction as to the necessity for special group protection in addition to that sought to be accorded to the individual.

minority and majority including the right to form their own organizations, to hold meetings, and to maintain their own press; (2) the right to primary school education in their own language and to secondary education in their own schools; (3) recognition of Croat and Slovene languages as official for administrative and judicial purposes in areas where minorities are resident; (4) the right to share equally in the judicial and administrative system in these areas; and (5) the right to protection against activities of any organization designed to deprive them of their minority character and rights. N. Y. Times, Aug. 25, 1949, p. 9, col. I.

'See, for example, Albanian Const. Art. 35, guaranteeing national minorities the right to enjoy equality of treatment with other citizens and the freedom to use their own language and develop their own culture; Australia, Sec. 5r, empowering Parliament to enact legislation with respect to the people of any race for whom it is deemed necessary to enact special laws; Belgium, Art. 23, providing that the use of languages in Belgium is optional and that legislation may be enacted for its regulation with regard to the acts of public authorities and for judicial proceedings; Brazil, Art. 168, requiring that all primary schooling be given in the national language; Bulgaria, Art. 79, granting national minoritics the right to be educated in their vernacular and to develop their national culture; Burma, Art, 22, prohibiting discrimination with regard to the admission into state educational institutions against religious, racial, or linguistic minorities and prohibiting the imposition of religious instruction upon stuch minorities; Bylo Russian Sov. and Soc. Rep. Art. 86, guaranteeing minorities free use of their language in judicial proceedings; Canada, (Br. N. Am. Act 1867 , sec. 133), providing for use of English or French in legislative debates and judicial proceedings; China, Art. I68, providing that legal protection is to be accorded to racial groups in the border areas and that the state shall take positive action for the devclopment of educational culture, public health, and economic and social cnterprises of racial groups in the border areas; Czechoslovakia (draft of new constitution not available); Finland, Art. 14, providing that both Finnish and Swedish shall be the national language; Italy, Art. 6, declaring it to be the duty of the state to protect linguistic minorities; Panama, Art. 81, requiring authorization in order to teach in a foreign language, and Art. 94, guaranteeing special protecting to peasants and indigenous communities in order to integrate them into the national life and yet to preserve and develop the value of their autochthonous culture; Transjordan, Art. 2r, conferring rights on various "societics" to cstablish and maintain their own schools; Ukranian Soc. Sov. Rep. and U.S.S.R. (see provisions of Const. of ByloRussian Soc. Sov. Rep.); Yugoslavia, Art. 13, extending the right to national minoritics to cnjoy their own cultural development and free use of their own language. YeArbooK of THE UNITED Nations, 1947; also U. N. Doc. E/C.N. $4 /$ Sub. $2 / 4$ (Oct. 8, 1947).

'In the United Nations Charter is recorded the solemn obligation of the member nations to promote and encourage universal respect for, and observance of, human rights and fundamental freedoms for all without distinction as to race, sex, language, or religion (Arts. $1,13,55,56,76$ ); and to develop friendly relations among nations based on respect for the principle of equal rights and self determination of peoples (Art. I). U. N. Charter (Dep't State Pub. 2353, Conf. Ser. 74).

On December 10, $x 948$, the General Assembly unanimously approved a Declaration on Human Rights enumerating the basic civil, political, economic, and social rights which should be secured to every individual in pursuance of the U. N. Charter provisions. For text, see Dep't State Pub. 3381 (Int. Org. and Conf. Ser. III, 20) U. N. Doc. No. A/8Ir, Dec. 16, 1948.

${ }^{7}$ See infra pp. 624-626. 
In order to assess these difficulties, and to explore the potentialities of international protection for group rights, it is necessary to have some understanding first, of the basic problems of minorities and second, of the experience of the League of Nations in what represented the first attempt on the part of the international community to implement minority protection by the collective guarantee of a neutral international organization.

\section{The Problem of Minorities}

Groups differing from a majority of the population by reason of their race, language, or religion exist throughout the Western Hemisphere, ${ }^{8}$ Europe, ${ }^{\theta}$ the Middle East, ${ }_{9}^{10}$ and the Southeast Asian area. ${ }^{11}$ In some cases, the presence of minority groups in these areas has resulted from entirely voluntary immigration; ${ }^{12}$ in other cases it has been brought about by conquest or wartime territorial transfers; ${ }^{13}$ and in still others as a result of treaty commitments unrelated to such wartime transfers. ${ }^{14}$

Frequently a close correlation exists between the origin of the minority and its general attitude towards the members of the dominant group to which it is attached. Both factors are influential in the policy of the majority towards its minority groups. Thus a minority which has voluntarily emigrated to a country such as the United States, for example, attempts to assimilate itself as quickly as possible into the American way of life. It therefore affords less provocation to the dominant group

${ }^{8}$ For discussion of minority groups in the United States, see Nelson, Religion and Racial Tension in Ametica Today in Appronches to Natronse UnITY 544 (I945); and Ascoli, The Italian Americans in Group Rezattons aNd Group ANTAgonisms 31 (I944); for similar discussion of minority groups in Latin America, see Tannenbaum, Minorities in Latin America in Group Relations and Group ANTAgoNISMS I7I (I944).

${ }^{\circ}$ In eleven East-Central European States, for example, the proportion of minorities in the total population ranges from a low of 8 per cent (Czechoslovakia) to a high of $3^{r}$ per cent (Poland). The number of minority groups in each state ranges from two (Albania) to eight (Yugoslavia). For more complete data, see Cole, Europe's Conflict of Cultures in Group Relations and Group ANTagonisms r21 (1944); also Oscar I. Janowsky, Nationalittes and National Minorittes (1945).

10 A. Hourami, Minorities in the Arab World (I947).

${ }^{11}$ Most of the Southeast Asian nations and territories are populated by Indians, Chinese, Hindus, and a variety of other miscellaneous racial and nationality groups. For details on minority problems and cultural frictions in Burma, see C. H. T. Crosthwaite, The Pacification of Burma (rgi2); for Indonesia, see John S. Furnivalx, Netherdands India (r944), and Indonesia: Crosstoads in American Policy, I American Perspective 382 (1947); for the Malayan Peninsula, see Rawlings, Malaya (Pamph. 1945); and Barnett, Malaya in Development of Self Rule and Independence in Burma, Malaya and THE Philippines; for India, see Shridharani, Minorities and the Autonomy of India in Group Relations AND Group ANTAGonisMs I99 (1944).

${ }^{13}$ For example, in the United States and in certain of the Southeast Asian countries.

${ }^{13}$ Europe of course constitutes the best example of this type, see note 9 supra.

14 Perhaps the most familiar example of this type is the Indian immigration into South Africa during the 19th century. For summary of the history of Indian immigration and attempted assimilation in South Africa, see documents submitted by India and South Africa to the United Nations in connection with Indian charges of violations by South Africa of its human rights obligations assumed under the U. N. Charter, summarized by Gross, The Impact of the United Nations Upon Domestic Jurisdiction, I8 Dep't State Bult. 263 (I948); also U. N. Docs. A/68 (Aug. 26, 1946), and A/373 (Sept. 2, I947) (Indian Memoranda). 
to take discriminatory measures against it or to adopt policies of enforced denationalization. Generalization on this point, however, is impossible. Thus in South Africa, although the Indians immigrated originally as contract laborers, they remained voluntarily and attempted to assimilate themselves to South African customs. Their efforts met with immediate resistance from the South Africans, who represented the dominant and more advanced cultural group although a numerical minority ${ }^{15}$ Only recently the South African government has announced that it will enforce a rigid policy of segregation of races accompanied by affirmative attempts to awaken the cultural consciousness of the negro and Indian members of its population. ${ }^{10}$ In many Southeast Asian countries, while immigrant groups came voluntarily, many maintained a rigid sense of group solidarity, refusing to assimilate to what they regarded as a culturally inferior way of life. Many were unable to live peacefully alongside the majority group and suffered frequent economic discrimination and occasional personal violence. ${ }^{17}$ A similar history of discrimination, violence, enforced denationalization, or compulsory migration or expulsion has characterized the experiences of numerous European sub-cultural groups ${ }^{18}$. which have clung tenaciously to their own tradition, folklore, and cultural patterns regardless of the political state under whose aegis the exigencies of war and conquest placed them. Yet both Switzerland ${ }^{19}$ and the Soviet Union ${ }^{20}$ and to a lesser extent Czechoslovakia attest to the possibility of maintaining cultural autonomy without intergroup friction and tension.

It is difficult to formulate a definition of a minority which would cover these diverse groups. It is obvious that such a definition cannot be based on a classification of minority groups in terms of their origin, the political organization of the host state, the degree of desired assimilation, or the relative economic and cultural superiority of the minority and majority. A common definition describes the term minority as referring to "groups of persons who differ in race, religion or language from the majority of the inhabitants of the country."21 The very simplicity of the definition, however, tends to obscure the dual nature of the minority problem. On the one hand, a minority exists if its members look upon themselves as possessing a distinct national consciousness accompanied by linguistic and/or cultural characteristics which differ from those prevailing among the majority. ${ }^{22}$ National conscious-

\footnotetext{
${ }^{15}$ For summary of South African policies adopted towards its Indian population, sec U. N. Doc. A/68 (Aug. 26, 1946) and A/373 (Sept. 2, 1947); also N. Y. Times, July 12, 1949, p. 9, col. 5.

${ }^{16}$ Christian Science Monitor, Aug. 6, 1949, p. 4 .

17 See note 4 supra.

${ }^{18}$ See note 9 supra.

${ }^{10}$ JANowsky, op. cit. supra note 9, at 37 .

20 Id. at 69 .

21 This is the definition suggested by Rosting, Protection of Mrorities by the League op Nations (1922); similar definitions have been advanced by Leyburn, WorLd Minority Pronlems 2 (Pub. Aff. Pamph. No. 132). Cf. definition of minorities adopted in the Minoritics Treaties, note 3I, infra and tentatively by the U. N., note 126 infra.

22 Pablo y Florel de Azcarate, League of Nations and National. Minorities 13 (1945); Rovcek, The Minority Principle as a Problem of Political Science 22 (Pamph. undated); Sulkowski, The
} 
ness in this sense is not used to indicate political affiliation. It is essentially a psychological manifestation indicating a feeling of solidarity among members of a group who share common traditions, historical perspectives, and principles irrespective of whether that group has ever formed or been part of a political state or not. If an individual does not share these ideals with others in a group he does not belong even though he may be of the same race, speak the same language, and live in the same territory. On the other hand, members of a society may "create" a minority in their midst through their discrimination against certain members by reason of their religion, race, sex, color, social class, and the like, irrespective of whether these individuals entertain a national consciousness and sense of difference apart from the majority or not. It is this dual nature of minorities as embracing both "self made" and externally "created" groups which must be clearly perceived if effective and constructive solutions are to be found for the general problem of group frictions. Nor can the fact be ignored that many groups differing from the majority by race, language, or religion live peacefully alongside the majority and present no problems of this kind.

Anthropologists, religious leaders, and psychologists, discussing the possible solutions for this problem, agree that many of the causes of such frictions and tensions lie deeply rooted in the make-up of the human personality, ${ }^{23}$ and can only be removed through a lengthy process of enlightenment and education. At the same time they disagree as to whether the problem is more appropriately approached through a renewed emphasis on the dignity of the human person, ${ }^{24}$ or whether a more political approach is necessary whereby the state would recognize a type of cultural autonomy for the diverse elements of its population. ${ }^{25}$ The argument in favor of the latter approach proceeds on the democratic assumption that there is value in heterogeneity and that human progress depends on a variety of cultural patterns and on the consequent impact of clashing ideas. Although seemingly inconsistent, the two approaches are reconcilable in terms of the type of minority which is involved. Thus emphasis on human dignity unless broadly construed would not suffice to cope with the problems encountered by the so-called "self made" minorities. On the other hand, application of a system of protection designed to guarantee cultural autonomy to an externally "created" minority would be productive of greater problems, difficulties, and deprivations than it could possibly hope to eliminate.

Problem of National Minorrties in its Sociologtcal Aspects 5-7 (1943). A similar definition was put forward many decades before by J. S. MrLl, Considerations on Representattve Government 287 (1875).

${ }^{28}$ See generally Lyman Bryson, Louis Finkelstein and R. M. Maciver (Eds.), Approaches to NAtTonal UNITY (Symposium published by Conference on Science, Philosophy and Religion in their Relation to the Democratic Way of Life, Inc., (I945)); and especially Havighurst, Education for Intergroup Cooperation, id. at 387 .

24 Finkelstein, The Jewish Minority in Group Relations and Group ANTAgonisms 85, 94, 95 (1944).

${ }^{25}$ Janowsky, Ethnic and Cultural Minorities in Group Relations and ANTAGONISMS 157, I68 (I944); Maclver, op. cit. supra note I. 
It is clear, however, that effective action with respect to the alleviation of minoritymajority frictions-regardless of its nature-will prove unsuccessful if the problem is regarded as relating solely to the protection of the group against hostile state action. The Nazi exploitation of German minorities in neighboring states in furtherance of its infiltrative and other subversive policies illustrates in graphic fashion the type of problem which the presence of minorities may present to the state. Recent fears expressed with regard to possible pro-Russian sentiments among Yugoslavian minorities, and pro-Chinese sentiments among Indonesian minorities ${ }^{26}$ reflect the continuing importance of this aspect of minority-majority relations. It is against this background of the problem that the question of international protection of minórity rights must be considered.

II

\section{International Protectton of Minority Rights Under the League of Nations}

\section{A. Development of the Concept of Minority Protection}

While international concern for the religious, civil, and political rights of minorities had been manifest as early as the sixteenth ${ }^{27}$ and more particularly during the nineteenth centuries, ${ }^{28}$ effective implementation of this concern by means of an international guarantee had not been attempted until the peace settlements following World War I.

As originally conceived by President Wilson, the principle of self determination through territorial revision was to be supplemented by a system of minority obligations imposed by the League of Nations Covenant on all new states and all states seeking admission to the League. Such obligations were to include guarantees of religious freedom to all inhabitants and equality of treatment between minorities and majorities. ${ }^{29}$ Wilson's proposal for the incorporation of such guarantees in

${ }^{28}$ See, for example, N. Y. Times, Aug. 23, 1949, p. 6, col 3; N. Y. Herald Tríbune, Aug. 30, 1949, p. 22 , col. 5 .

${ }^{27}$ In the treaties concluded with the Ottoman Empire (capitulations) and later extended to the Far East, provision was made for the exercise of extraterritorial jurisdiction to be exercised by the diplomatic agents of the Christian powers over their subjects residing in these countries, thus affording a type of protection to religious and national minorities within the states. Sulkowski traces the first modern effort to protect religious minorities back to the Treaty of Augsburg in 1555 and the Treaty of Westphalia in $x 648$, guaranteeing religious freedom to the states. Sulkowsri, The Pronlem op INTERnational Protection of Nationaz Minorities 6-7 (1944). •

${ }^{28}$ The various treaties concluded in this century relating to the protection of individual rights are collected and summarized in L. P. Matr, The Protection of Minorimes 30-34 (1928). They include the Congress of Vienna (1814) guaranteeing the equality of Dutch citizens and religious frecdom; the Protocol of 1830 relating to the establishment of the Kingdom of Greece, guarantecing freedom of religion to all Greek subjects; the Conference of Constantinople (1856) guarantecing religious freedom and equality of civil and political rights to Moldavians and Wallachians; and the Congress of Berlin ( 1878 ) guaranteeing similar rights to the inhabitants of Rumania, Serbia, Montenegro, and Bulgaria in order to protect the Jews and Moslems from discrimination. See also 5 Harold W. V. TemperLey (Ed.), A History of the Pence Conference of Paris II2, ri 4 (I92I).

${ }_{20}$ In Wilson's second draft of the League Covenant submitted in January, 19rg, he proposed the inclusion of an article which provided that:

"The League of Nations shall require all new states to bind themselves as a condition precedent to their recognition as independent or autonomous states, to accord to all racial 
the League Covenant, however, was rejected by the Supreme Council, in part because of the "extreme delicacy of the issues involved,"30 and the matter was left to be dealt with on a case to case basis in the peace treaties and territorial settlements. ${ }^{31}$ Among the states forced to accept such obligations, immediate opposition was raised by Yugoslavia, Rumania, and Poland, who protested that the system of minority protection as thus conceived constituted an infringement of their sovereignty, an impugnation of their good faith, and a violation of the principle of equality among nations. Resentment was particularly acute by reason of the fact that the Great Powers and more particularly Germany and Italy were not required to assume comparable obligations. ${ }^{32}$ Their objections proved unavailing and as the system finally emerged, ten states, primarily in central and eastern Europe, which as a result of territorial adjustments contained substantial minority groups, were required to

or national minorities within their several jurisdictions exactly the same treatment and security, both in law and in fact, that is accorded to the racial or national majority of the pcople."

In his third Covenant Draft, Wilson proposed the inclusion of an additional article on religious freedom providing that:

"Recognizing religious persceution and intolerance as fertile sources of war, the Powers signatory hereto agree, and the League of Nations shall exact from all new states and all states seeking admission to it the promise, that they will make no law prohibiting or interfering with the free exercise of religion, and that they will in no way discriminate, either in law or in fact, against those who practice any particular creed, religion or belief whose practices are not inconsistent with public order or public morals."

2 David H. Miller, The Drafting of the Covenant 9r, io5 (xg28).

${ }^{30}$ Opposition in the Supreme Council to the inclusion of minority obligations in the League Covenant was led most vigorously by the British delegate, Lord Robert Cecil. MrLLER, op. cit. supra note 29, at $129-130,273-274,282,286-287$. The position of the Council had already been foreshadowed in the doubts expressed by David Hunter Miller as to the practicability of such generalized treatment for all minorities as was provided for in Wilson's second draft. MrLLER, op. cit. supra note 29, at 91 .

${ }^{31}$ Detailed minority obligations were assumed in the Peace treaties by Austria (Treaty of St. Germainen-Laye, Arts. 62-69); Hungary (Treaty of Trianon, Arts. 54-60); Bulgaria (Treaty of Neuilly-Sur-Seine, Arts. 49-57); and Turkey (Treaty of Sevres, Arts. 140-151, and Treaty of Lausanne, Arts. 37-45). For treaty texts, see I and 2 The Trentres of Pesce I9I9-1923 (Carnegie Endowment for International Peace, 1924).

In addition, Czechoslovakia, Poland, Rumania, Greece, Yugoslavia, and Armenia agreed to embody into a treaty "with the Principal Allied and Associated Powers such provisions as may be deemed necessary by the said Powers to protect the interests of inhabitants of that State who differ from the majority of the population in race, language, or religion." Treaty of Versailles June 28, 1949, Art. 86 (Czechoslovakia), Art. 93 (Poland); treaty of St. Germain-en-Laye, Sept. 10, rgr9, Art. 5 I (Yugoslavia), Art. 57 (Czechoslovakia), Art. 6o (Rumania); Treaty of Trianon, June 4, 1920, Art. 44 (Yugoslavia), Art. 47 (Rumania); Treaty of Neuilly-Sur-Seine, Nov. 27, 1919, Art. 46 (Greece); Treaty of Sevres, Aug. 10, 1920, Art. 86 (Greece), Art. 93 (Armenia).

Such treaties were subsequently concluded by Poland ( 3 Wilinam M. Malioy, Treaties, Conventions, International Acts, Protocols and Agreements between the Untted States and Other Powers 3714-3730, (1910-1923); Czechoslovakia (Id. at 3699-3708); Yugoslavia (Id. at 3731-3738); Rumania (Id. at 3724-3730); Greece (Protocol No. XVI attached to Treaty of Lausanne. 2 ThE Treaties of PEACE, supra, 789-944). The treaty of Armenia became null as a result of the absorption of that country into the U. S. S. R. (Id. at XXXVI).

${ }^{32}$ Austria, Bulgaria, Hungary, Greece, and Czechoslovakia, although critical of some aspects of the treaties, accepted the principle of minority protection more willingly. A summary of the principal arguments pro and con is contained in 5 Temperley, A History of the Peace Conference at Paris (I922); and Jacob Robinson and Others, Were the Minorities Treaties a Failure 15I-I68 (I943). A similar mixed reception was accorded the Minorities Treaties by the European Parliaments and press. Robinson, supra, I68-I74. 
assume minority obligations. Subsequently six other territories assumed similar obligations either by unilateral declaration, ${ }^{33}$ or by bilateral treaty. ${ }^{34}$ Although the United States signed the minorities treaties concluded with Yugoslavia, Rumania, Czechoslovakia, and Poland, she failed to ratify these instruments and thus was not formally a part of the minority system.

The obligations assumed by these states fell roughly into four categories. The first, embracing citizenship rights, defined the conditions under which citizenship could be acquired. ${ }^{35}$ In the second and third categories were included rights of life, liberty, and religious freedom of general applicability to all inhabitants; ${ }^{30}$ and civil and political rights for all nationals, including equality before the law and equal access to civil service, business, and profession as well as the use of their own language in religion, press, and assembly. ${ }^{37}$ Finally, certain special rights, designed to protect

${ }^{83}$ In Dec. rgao, the Assembly recommended that the Baltic and Caucasian States and Albania, in the event of their being admitted to the League, take necessary measures to enforce the principle of the Minorities Treaties and arrange with the Council to carry this object into effect. Finland madc such a declaration on June 27, 1921, with respect to the inhabitants of the Aaland Islands (2 LEAGUE of NATroNs, Offricraz Journar yor-702 (r921) (hereafter cited as $\mathrm{O}$. J.)); Albania signed a similar declaration on Oct. 2, 1921 (2 O. J. I16I-II64 (1921) and 4 id. 1466 (1923)); and Lithuania on May 15, 1922 (3 id. 536-537, 586-589 (1922); 5 id. 332-333 (1924)); Latvia on July 7 , 1923 ( 4 id. 933, 1275 (1923)); Estonia on Sept. 17, 1923 (4 id. 1310-1312 (1923)); and Iraq on July 13, 1932 (33 id. 1557 (1932)).

st Poland and Germany concluded a Convention on May 15, 1922, providing for reciprocal protection of Polish and German minorities in Upper Silesia (Text of Convention can be found in JuL.us Stone, Regional Guarantees of Minority Rights 213-262 (1933)); Lithuania concluded a convention relating to the Territory of Memel with the British Empire, France, Italy, and Germany on Oct. 3, 1924, under which Lithuania agreed to apply the terms of her Declaration (note 33 supra) to the inhabitants of Memel. 29 League of Nattons, Treaty Series 85 and 91 (1924) (hereafter cited as League Tr. SER.). Poland and the Free City of Danzig signed a Convention extending the same guarantees assumed by Poland under its treaty with the Allied Powers (note 3r supra) to the minorities in Danzig (Art. 33) (6 LEAGUE TR. SER. I89-207 (1921)); Poland and Czechoslovakia by Convention of April 23, 1925, agreed to extend the treatment and protection of their mutual minorities to the Silesian territories of Teschen, Orava, and Spisz (48 LenGUE TR. SER. 287-381 (1926)); and finally Czechoslovakin and Austria executed the treaty of Brunn on June 7, r920, which included detailed provisions with regard to the acquisition of nationality (Arts. I-I6) and the rights of their respective minoritics with regard to the use of their mother tongue and admission to educational institutions. (Arts, 17-19) (3 Lenoug TR. SER. $189-207$ (I I 2 I )).

${ }^{85}$ The general criteria of citizenship, adopted by most minority states, conferred automatic citizenship rights on those individuals who had tesided habitually in the territory, or whose parents maintained such habitual residence, or who had been born in the territory and had no other nationality. (Poland, Arts. 3-6; Czechoslovakia, Arts. 3-4; Rumania, Arts. 3-4; Yugoslavia, Arts. 3-4).

In the Austrian and Hungarian treaties, citizenship was automatically conferred on all persons possessing on the effective date of the treaty rights of citizenship (pertinenza) (Austria, Art. $6_{4}$ and Hungary, Art. 56). In the Bulgarian treaty, on the other hand, only persons who were habitually resident in the country on the effective date of the treaty were eligible for citizenship (Art. 5x). The Turkish treaty contained special nationality provisions apart from the general provisions found in all the peace treaties.

${ }^{30}$ Art. 2 of the Polish treaty, typical of the obligations undertaken in this respect by all the minority states, provides that:

"Poland undertakes to assure full and complete protection of life and liberty to all inhabitants of Poland without distinction of birth, nationality, language, race or religion.

"All inhabitants of Poland shall be entitled to the free exercise, whether public or private, of any creed, religion or belief, where practices are not inconsistent with public order or public morals." 3 Mat.Loy, op. cit supra note 3I, at 3717 .

${ }^{87}$ See, for example, Art. 7 of the Polish treaty (note $3 \mathrm{I}$ supra) which provides that: "All Polish nationals shall be equal before the law and shall enjoy the same civil and 
their cultural identity, were guaranteed to all nationals belonging to racial, religious, or linguistic minorities. These rights included the free enjoyment of equal treatment and security in law and in fact with other nationals; the receipt of primary school education in their own language; the right to establish under their own control charitable, educational, social, and religious institutions; and the right to share equitably in the enjoyment and application of public funds allocated for educational, religious, or charitable purposes. ${ }^{38}$ In addition, certain of the treaties contained special provisions for the protection of particular minority groups, ${ }^{39}$ such as the Jews in Poland, ${ }^{40}$ the Mussulmans in Yugoslavia, ${ }^{41}$ the Saxons and Czecklers in Rumania, ${ }^{42}$ the Ruthenians in Czechoslovakia, and certain others. ${ }^{43} \mathrm{~A}$ majority of the states making unilateral declarations of adherence to the minority system adopted substantially similar obligations. ${ }^{44}$ The bilateral arrangements, on the other hand, frequently contained more elaborate and detailed substantive provisions relating to the educational rights of minorities and other matters. ${ }^{45}$

political rights without distinction as to race, language or religion.

"Differences of religion, creed or confession, shall not prejudice any Polish national in matters relating to the enjoyment of civil or political rights, as for instance admission to public employments, functions and honors, or the exercise of professions and industries.

"No restriction shall be imposed on the free use by any Polish national of any language in private intercourse, in commerce, in religion, in the press or in publications of any kind, or at public meetings.

"Notwithstanding any establishment by the Polish Government of an official language, adequate facilities shall be given to Polish nationals of non-Polish speech for the use of their language, either orally or in writing, before the Courts." Id. at 3718 .

${ }^{88}$ Sec, e.g., Articles 8 and 9 in the Polish Treaty. Ibid.

${ }^{80}$ In the Treaty of Sevres, for example, Turkey assumed a special obligation to respect the ecclesiastical scholastic autonomy of all racial minorities. (Art. I49).

${ }^{20}$ Poland agreed to the establishment by the Jews of Educational Committees to distribute the public funds received for educational purposes and to organize and manage the Jewish schools. (Art. ro). In addition Poland obligated herself not to compel the performance of any act by a member of the Jewish minority which would constitute a violation of the Sabbath. (Art. II).

"Art. Io of the Yugoslavian Treaty (note 31 supra) granted the Mussulmans virtual autonomy in matters of family law and personal status and guaranteed the protection of their mosques, cemeteries, and other religious establishments.

${ }^{2}$ Art. II of the Rumanian Treaty (note 3 I supra) guaranteed the Saxons and Czecklers scholastic and religious autonomy.

${ }^{43}$ Czechoslovakia undertook to accord the fullest political autonomy to the Ruthenians in the Carpathian Territory. (Arts. 10-12).

"An exception was the Finnish Declaration (note 33 supra) in which Finland bound itself to guarantee to the population of the Aaland Islands the preservation of their language, culture, and local Swedish traditions (Art. I), and specifically the compulsory use of Swedish in the schools, the continued ownership of property solely in hands of legal residents, and the right to use 50 percent of tax revenues for Aaland Island purposes.

${ }^{45}$ See, for example the Czech-Polish Convention relating to Silesian Teschen, Orava, and Spisz in which specific provision was made that the upholding of minority rights should not be regarded as an act of disloyalty (Art. 12) and that no pressure should be exercised with a view to persuading parents to send their children to a school which did not teach in the language of their mother tongue (providing expressly that the declaration of the individual as to his mother tongue could not be disputed) (Art. 13). The use of their own language in the courts and other official bodies was spelled out in considerable detail (Arts. I4-16), as were the educational rights granted to minorities (Arts. 17-21). See also Brunn Convention executed by Czechoslovakia and Austria (note 34 supra) containing detailed provisions with respect to educational rights of their minorities, and the German Polish Convention relating to Upper Silesia (note 34 supra). 
Under the general minorities treaties each state bound itself to incorporate these provisions into its fundamental law and acknowledged that in so far as the stipulations affected persons belonging to racial, religious, or linguistic minorities they constituted obligations of international concern and were to be placed under the guarantee of the League of Nations. ${ }^{46}$ It was further recognized that any member of the League Council should have the right to bring any infraction or danger of infraction of minority rights to the Council's attention and that the Council would then take such steps as it deemed proper. Finally, each signatory state agreed that any difference of opinion as to questions of law or fact arising with respect to the treaty obligations was to be submitted to the Permanent Court of International Justice.47

In addition to this general system of minority protection, special regional procedures existed for the settlement of minority disputes arising in Danzig, Silesian Tseschen, and Upper Silesia. ${ }^{48}$ In the Convention on Upper Silesia, ${ }^{40}$ the most elaborate of the regional procedures established, rights of petition and appeal were expressly granted to individual members of the minority, ${ }^{50}$ and investigatory and adjudicatory functions were conferred on special local bodies, which included a Minorities Office in the state to which the minorities belonged, ${ }^{61}$ a Mixed Commission

\footnotetext{
${ }^{10}$ Thus under the so-called guarantee clause the stipulations guaranteeing general rights and freedom to all inhabitants or nationals (other than members of minority groups) were exempted from the League enforcement system, although they remained at least in theory as an international obligation of the signatory state.

Some question arose as to whether the nationality provisions of the Minorities Treaties were subject to the League Guarantee. One author states categorically that they were not. L. P. MARr, The ProTECTION OF MinoRimes 220 (1928). The Permanent Court would seem to have answered the question in the negative. Acquisition of Polish Nationality, Ad. Op. 7, Sept. 15, 1923, I ManzeY O. Hudson, World COURT RePorts 237.

${ }^{17}$ See, e.g., Art. 12 of the Polish Treaty, 3 Marcoy, op. cit. supra note 31, at 3719. Substantially similar procedural obligations were accepted by those states adhering to the system by Declaration.

Finland agreed to place her guarantees with respect to the Aaland Islands under the protection of the League; to transmit to the League any petitions submitted to the Landsting of Aaland in connection with violations of these guarantees; and finally to consultation of the Permanent Court by the Council in the event of a juridical dispute. (see note 33 supra). In the Latvian and Estonian Declarations, the right of the League to accept and transmit petitions to the Council relative to alleged minority infractions was recognized and an obligation assumed to furnish the League on request with appropriate information; finally the Permanent Court was acknowledged as competent to give an advisory opinion on questions of law or fact arising out of the Declarations (note 33 supra).

${ }^{48}$ In the Polish-Danzig Convention (note 34 supra), provision is made for the submission of disputes first to the High Commissioner and second to the League Council-this it would seem constitutes an additional procedural machinery for the settlement of minorities disputes.

Similarly in the Czech-Polish Convention relating to Teschen, Orava, and Spisz (note 34 supra) both a mixed commission and an arbitral tribunal were established for the settlement of disputes arising out of the interpretation of the Convention (Arts. 73-8r). Similar machinery was established in the Brunn Convention by Austria and Czechoslovakia (Arts. 21-30) (note 34 sttpra). Note, however, that in the Brunn Convention the signatories expressly provided that disputes arising out of the Convention should not be submitted to the Permanent Court (Art. 3I). This provision, however, would not affect either Czech or Austrian obligations in this respect under their Minorities Treaties concluded with the Allied and Associated Powers. (Note 31 supra).

${ }^{40}$ See note 34 supra.

${ }^{50}$ Art. 147.

"1 Arts. 148-152, which constituted in effect an informal administrative appeal body charged with the duty of receiving and examining petitions after the complainant had exhausted his appropriate remedies under state law.
} 
composed of representatives of both states and presided over by a neutral President, ${ }^{52}$ and an Arbitral Tribunal.53 In addition, recourse was permitted to the League Council in the event that satisfaction was not available under the regional machinery. ${ }^{54}$

Thus amidst the bitter opposition of some states and the lukewarm support of others, the minorities experiment was inaugurated. From its inception, the concept of minority protection was regarded as a political rather than a humanitarian measure-one designed to avoid friction and to eliminate elements of disturbance in those European states which either had received substantial territorial accessions or were newly constituted but contained heterogeneous populations. As Clemenceau pointed out in his famous letter to Paderewski, ${ }^{55}$ at that time Foreign Minister of Poland, while the concept of minority protection constituted no innovation in international practice, the system of enforcement by an international body marked a new precedent designed to prevent unwarranted political interference in the domestic affairs of a state by one or several powers and to provide instead for supervision of such rights by a neutral international authority. The justification for the system, according to Clemenceau, lay in the Allied conviction that because of the new territorial arrangements under which populations had been shifted to new sovereignties, "these populations will be more easily reconciled to their new positions if they know that from the very beginning they have assured protection and adequate guarantees against any danger of unjust treatment or oppression."

While these statements reflect the basic impetus for the establishment of the system, the League's concept of its responsibilities under the treaties is best reflected in the statement of the French diplomat, Aristide Briand, made to the Assembly in I929. Briand declared: ${ }^{50}$

It is in no way to the interest of a country that the element of its population which has its own value and its own characteristics should disappear and a great country which realizes its own strength does not endeavor to bring about any such disappearance. It does not try to reduce its population to a uniform level. On the contrary, the strength of a country consists in assimilating various elements of its population without letting them lose their own characteristics and qualities. It is in this way that a country develops and acquires its full strength which enables it to expand. Those who think of reducing a country to one uniform pattern by suppressing the individual characteristics of each of the elements of its population are doomed to many reverses. . . . That, however, is not the real problem. The real problem is, while ensuring that the minorities shall pre-

\footnotetext{
${ }^{52}$ Arts. 152-156. In all cases where the complainant failed to receive satisfaction from the Minorities Office, the latter was bound to forward the petition to the Mixed Commission for its opinion. The Mixed Commission was empowered to make whatever investigation it deemed necessary and to recommend either a partial, final, or provisional solution.

${ }^{53}$ Arts. 158,588 . Any question of interpretation was to be submitted to an Arbitral Tribunal, whose decisions should be binding on all parties.

* Art. 157 .

to Letter dated June 24, 19I9, reproduced verbatim in 5 TEMPERLEY, op. cit. supra note 28 at $432-437$ (App. IV).

do League of Nations, Protection of Linguistic, Racial or Religious Minorities by the League of NAtions roi-IO2 (C. 8.M.5. 1931. I).
} 
serve their language, culture, religion and traditions to keep them as a kind of small family within the larger family not with the object of weakening the larger family, but with the object of harmonizing all its constituent elements with those of the country as a whole. The process at which we aim is not the disappearance of the minorities but a kind of assimilation which will increase the greatness of the nation as a whole without in any way diminishing the importance of the smaller family. That is how I understand the problem of minorities.

\section{B. Minorities System in Operation ${ }^{67}$}

Since the minorities treaties contained only brief reference to the manner in which the League was to fulfill its guarantee of minority rights, ${ }^{68}$ at the outset the League Council had to devise its own procedural rules. In October, I920, after considerable debate on the nature of the guarantee ${ }^{50}$ assumed by the League, the Council adopted a resolution which established the basic procedural machinery for the submission and consideration of minorities questions. ${ }^{60}$ This system was characterized by two main features: first, the establishment of a right of petition in favor of non-Council members as well as the minorities themselves or persons acting on their behalf; and second, the creation of minorities committees, composed of three Council members, charged with the duty of examining all petitions submitted and making recommendations to the Council as to whether it should take action or not. Impetus for the institution of this procedure stemmed from the desire of the Council members to avoid the "invidious" and "thankless" task of acting as an accuser of a sister state by virtue of the minorities treaty provisions requiring that alleged violations of minority obligations be brought to the Council's attention by a Council member. ${ }^{61}$ But the resultant advantages accruing to minority groups by reason of the petition system evoked immediate opposition from the minority states, who challenged the legality of the procedure and protested that its only effect was to grant to minorities and other states a new vehicle for irredentist and other hostile propaganda and thereby to impede the peaceful adjustment of minority-majority

57 The material which follows in this and succeeding sections will deal with the operation of the general minorities system as distinguished from the regional systems such as prevailed in Upper Silesia. References to the latter will be made from time to time in the footnotes to indicate the major differences between the two systems.

58 Three provisions were made: (I) that the minority provisions were to be made a part of the fundamental law of the land; (2) that any dispute relating to an infringement-actual or potential-was to be referred to the League Council; and (3) that any question of law or fact arising out of the interpretation of a minority treaty was to be submitted to the Permanent Court of International Justice. See notes 46 and 47 supra.

${ }_{59}$ Pursuant to Council direction M. Tittoni (delegate from Italy) submitted a Report to the Council on this question in which he concluded that $(x)$ the minorities provisions were inviolable and incapable of modification without Council approval; (2) the Council bad both a right and duty to see that the minorities provisions were observed and to take action in the event violations occurred; and (3) that the Council had no legal obligation to accept the guarantee but that its repudiation would be politically impossible. Protgction of Limguistic, Raciar or Religious Minorities ax the Lengut of Nations, supra note 56 , at 5 .

${ }^{\circ 0}$ Adopted at the roth session of the Council, Oct. 22, I920. Protecrion of Lincuistrc, Rncinis on Retigious Minorities, supra note 56, at 9-1I.

${ }^{62}$ See particularly remarks - of Lord Balfour (United Kingdom) and M. Hymens (Belgium) in the Ioth session Council debate. Ibid. 
relations. ${ }^{62}$ The League refused to accede to the arguments based on the illegality of the system and was eventually sustained in this position by the Permanent Court of International Justice, which ruled that the Council had a right to regulate its precise procedure and that it was immaterial how or by whom a member of the Council was induced to bring minorities questions to the attention of the Council..$^{63}$ The League, however, did agree to the introduction of certain modifications of the procedure, designed to safeguard the minority states against unjustified accusations. Under these amendments, conditions for the receivability of petitions were laid down, ${ }^{64}$ opportunity was afforded the state concerned to submit its observations and comments on the facts alleged in a petition prior to its distribution, ${ }^{65}$ communication of the petition plus the governmental observations if any were restricted to Council members only rather than circulated to all League members as had been the practice, ${ }^{60}$ and, finally, eligibility of membership in the minority committees was confined to delegates of non-interested states in order to insure complete impartiality. ${ }^{67}$

As the system worked out in practice, the great bulk of the minorities work was performed by the Minorities Section which acted as a technical secretariat charged with the responsibility for securing information; and by the Minorities Committees whose primary duty was the evaluation of these facts as they bore on the subject matter of the petition. When a petition was first submitted to the League, its receivability was passed upon by the Secretary General with the assistance of the Minorities Section. In general all signed petitions were regarded an emanating from an "authenticated source," even if they were submitted from persons or organizations which did not belong to the minority nor even to the country in which the

${ }^{02}$ In r921 and again in 1923 Poland and Czechoslovakia employed these arguments in support of their proposals for these amendments of the 1920 procedure: (I) that petitions be submitted in the first instance to the government concerned; (2) that no petitions should be received from international organizations; and (3) that petitions should be communicated only to Council and not all League members. Poland argued that the proposals were designed to reduce the load of the Council and to encourage minority groups to look to their own state rather than to foreign powers or to the League for redress of their grievances. Id. at 13-14; Letter of Benes (Czechoslovakia) April 5, I923 to Secretary General (4 O. J. 7I7 (I923)); Letters of Modzelewski and Askenazy (Poland) Jan. I6, I923 and Aug. 22, 1923 ( 4 id. 480 , 1023 (r923)): Report to Council of M. Rio Branco (Brazil) Sept. 5 , r923 (4 id. I426, Annex 558 (1923)).

${ }^{\circ 3}$ German Settlers in Poland. Ad. Op. No. 6, Sept. 10, 1923, I Manley O. Hudson (Ed.), World Court Reports 207 (I934-35).

* Resolution adopted by Council, Sept. 5, I923. Protection of Linguistic, Racial, or Religious Minorities, supra note 56 , at $7-8$.

Five criteria were established: (I) petitions must relate to minority protection as provided for in the Treaties; (2) must not relate to matters recently made the subject of petitions; (3) must not be submitted in the form of a request for the severance of political relations between the minority and the state to which it owed allegiance; (4) must not emanate from an anonymous source; and (5) must abstain from violent language.

${ }^{\circ 5}$ Resolution adopted June 27,1921 . Id. at 7.

${ }^{\circ 0}$ Resolution adopted September 5, 1923. Id. at 8.

or Resolution adopted June 10, 1925. Ibid. The Council ruled that no member of a Committee cstablished to investigate a petition could be a representative of the state to which the petitioning minority belonged; of a neighboring state, or of a state a majority of whose citizens "belong from the ethnical point of view to the same people as the minority in question." 
minority was attached. ${ }^{68}$ This practice was repeatedly challenged by the minority states $^{69}$ but was eventually sustained by the Permanent Court. ${ }^{70}$ Some of the difficulties $^{71}$ arising with respect to the question of receivability are illustrated by two cases brought before the League Council by Lithuania and Germany respectively. In both, the receivability of the petition was challenged on the ground that the persons whose rights had allegedly been infringed did not actually belong to a minority group within the meaning of the treaty. The issue turned on whether a question of status should be regarded as jurisdictional or substantive in nature. In the Lithuanian case, ${ }^{72}$ the Council ruled that the issue of status was one of substance to be determined after examination and did not affect the question of the receivability of the petition. In the German case, ${ }^{73}$ on the other hand, the question of status was referred by the Council to a Committee of Jurists which ruled in favor of receivability. The difference in treatment, however, may have been due to the fact that in the German case the issue involved an interpretation of the Upper Silesian Minority Convention, although it would not seem that the preliminary issue of receivability before the Council should have been treated differently on that account. In view of the fundamental importance and complex nature of the question of minority status, the Council's decision in the Lithuanian case would seem to offer a greater protection to minority groups, who might otherwise have found themselves denied all recourse to the League by a preliminary decision of the Secretariat adverse to such status, against which they had no appeal..$^{74}$

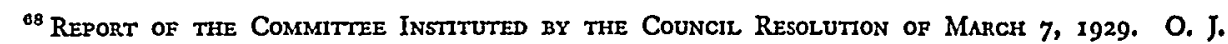
Spec. Supp. No. 73, 193 (1929), hereafter cited as the LonDon REPORT.

${ }^{\circ}$ See notes presented to Secretary General by Czechoslovakia and Poland urging procedural amendments to the minorities systems. Both objected to the fact that petitions were accepted from international organizations who had no connection with either the minority or the country concerned. See note 62 supra. Similar complaints were made by Hungary and Czechoslovakia with regard to minority petitions submitted against them which emanated from nonlocal sources. 7 O. J. I45 (I926); and C 49x. M. 354. I921. I.

${ }^{70}$ See note 63 supra.

${ }^{71}$ Azcarate deseribes the sleepless nights spent trying to decide whether the language in a petition was "violent" or whether the source could be regarded as "well established," questions of importance primarily for reasons of the principle which demanded that each petition regardless of the importance of the substantive questions raised be carefully and impartially considered. Pablo de Azcarate, Lengue on Nations and Nattonal Minorities IOg (1945); see also London Report, silpra note 68, at 193-194.

${ }^{72}$ Minutes of the 50 th Session of Council, June 6, 1928. Protection of Linguistic, Raciat on Religious Minorities, supra note 56, at 60-66 (1929).

${ }^{73}$ I4 O. J. 838-840, 934-935, Annex I451a (r933).

" Prior to 1929 the League considered itself under no obligation to notify the petitioner as to the fate of the petition. LONDON REPORT, supra note 68, at 194. It was simply acknowledged unless the Secretariat felt that the petitioner was ignorant of the conditions of reccivability, in which case their text was attached to the acknowledgment. Id. at 199-200.

In 1929 the Council resolved that petitioners be advised if their petition was declarcd nonreceivable and further that the Minorities Committees consider the advisability of soliciting additional information from petitioners when necessary. Resolution of June 13, 1929, Protection of Linguistic, Riacial or ReLigious Minorities, supra note 56, at II-12. The hesitancy of the League to enhance and formalize the role of petitioners was occasioned by unwillingness to approximate the minorities procedure in any way to that of a judicial proceeding whereby a state could be placed by its own subjects in the role of a defendant before an international body. The petition system was regarded primarily as an informational device to assist the Council in the discharge of its functions under the minorities tratics. Protection of Linguistic, Ractai or Religious Minorities, supra at ro6-I14, I29-137. 
Once the receivability of a petition was sustained, an intensive investigation of the facts involved was undertaken by the Minorities Section and later by the Committee to which it was referred. ${ }^{75}$ To the Minorities Section fell the task of communicating the petition to the government concerned and conducting whatever correspondence was necessary in order to ensure reasonable observance of the time limit within which its comments must be submitted. A detailed memorandum was then prepared summarizing the allegations and the observations of the government, together with such additional information as the Section was able to obtain on its own initiative through other channels. The major points on which the Committee would have to make a decision were carefully outlined, and the Director of the Minorities Section in presenting the case to the Committee frequently added his own observations and comments.

Preliminary examination of the petition by the Committee was then undertaken. In general the Committee refused to take action if the facts involved occurred before the inception of the minorities treaties, ${ }^{76}$ if the issue was at the time of the petition still pending before the authorities of the minority state, ${ }^{77}$ or finally if the alleged grievance related merely to an anticipated-rather than an actual-case of discrimination in the application of a statute which on its face appeared harmless. ${ }^{78}$

If the claims appeared to be clearly without foundation, the case was closed and the Council notified that no action was deemed necessary. If, on the other hand, the explanations of the government appeared unsatisfactory, the Committee opened negotiations with the government with the ostensible object of securing additional information. In fact, the negotiations were more frequently conducted for the purpose of inducing the state to adopt measures which would remedy the situation complained of and obviate the necessity for formally drawing the Council's attention to the dispute. The negotiations were generally carried on by members of the Minorities Section within certain broad objectives laid down by the Committee. Conferences were arranged with the governmental representatives either at Geneva or at the capital of the state concerned. In addition to these specific negotiations, members of the Minorities Section frequently made annual visits to the countries

\footnotetext{
75 The material which follows on the work of the Minorities Section and the Minorities Committees is based primarily on the London REPORT, supra note 68, at 42-64, and on AzCaRATE, op. cit. supra note 22, at rog-30x.

${ }^{70}$ See Committee's refusal to consider that portion of petition based on unwarranted refusal to induct petitioners into Czech army and consequent deprivation of pension rights by Czech government, on ground that facts relative to induction into the army occurred prior to effective date of Minority Treaty. 15 O. J. II2I (1934).

${ }^{77}$ See for example, petition by member of Hungarian minority in Czechoslovakia alleging unjustified denial of citizenship rights and threatened expulsion. Since the case was to be retried by the Czech

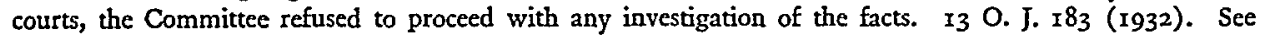
also C. 54. I926. I.

${ }^{78}$ This position was taken by the Committee with respect to a petition submitted by the Catholic, Reformed, and Unitarian Churches of Transylvania protesting the text of a Rumanian education law. The Committee noted that while the general text of the bill appeared satisfactory, certain of its features might give rise to doubt in its application in the future but that this question was premature. 70 . J. $741-742$ (1926).
} 
which had assumed minority obligations with a view to familiarizing themselves with the local conditions and problems and with the points of view of both official and nonofficial elements directly concerned with minority problems.

Where the Minorities Committees were unable to effect any compromise or modification of the situations complained of, formal recommendation might be made to the Council that it place the issue on its agenda. In essence the procedure followed by the Council was substantially similar to that undertaken by the Committees. The difference lay in the greater publicity and enhanced prestige and moral suasion attendant upon the Council's deliberations. ${ }^{78}$

While information on the substantive aspect of the Committees' work is not available in detail, some impression of the type of disputes which arose and the remedial measures taken can be gained from an examination of the Council records. A total of 521 petitions were received during the period from 1929 to 1939 , of which 225 were declared non-receivable. ${ }^{80}$ The facts complained of varied from charges of individual acts of discrimination and violence ${ }^{81}$-including alleged unjustified hiring and firing policies, ${ }^{82}$ denials of pension rights, ${ }^{83}$ non-recognition of citizen-

${ }^{79}$ AzCARATE, op. cit. supra note 22, at II8-irg.

${ }^{80}$ No statistics were published prior to the Council Resolution of June 13, 1929, supra note 74 . Thereafter they were published annually as follows:

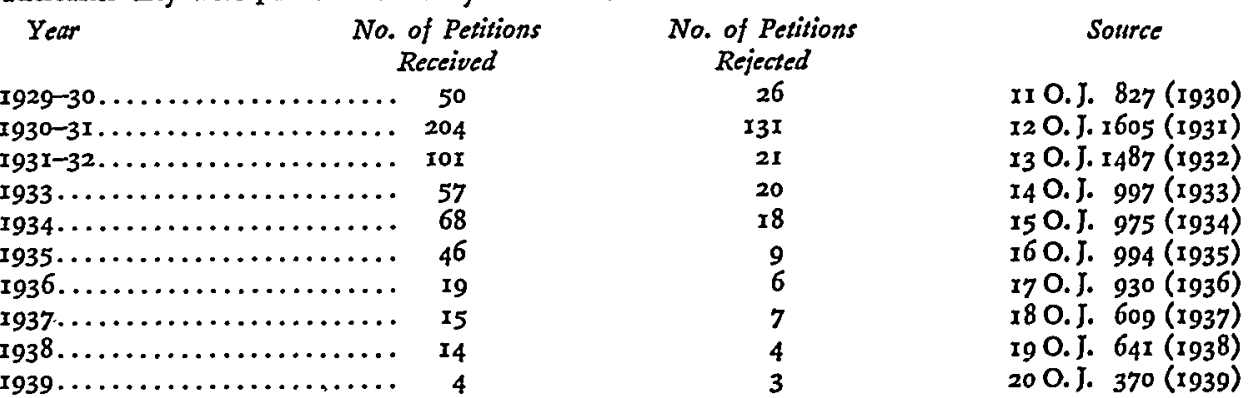

81 Azcarate, former member and Director of the Minorities Section, indicates that the great bulk of the petitions received by the League concerned complaints against acts of violence, repression, and tcrror meted out to minority groups and that in most cases little could be done to alleviate the situation. Azcarste, op. cit. supra note 22, at 66-73. Two problems reported in the Official Journal stemmed from individuals seeking compensation for injuries received in the course of public anti-minority demonstrations where the government had failed to take precautions or refused to punish the offenders. In the two reported cases the Committee concluded that the governments had not been delinquent and recommended no action by the Council. 15 O. J. 479, 976 (1934).

82 Two such petitions were submitted to the Council by members of the Hungarian and German minorities in Czechoslovakia. In the case of the former, the Committee found no evidence to justify petitioners' claim of unjustified dismissal from their jobs as railwaymen and recommended that no action be taken by the Council. I4 O. J. II20 (I933). In the other petition complaint was made of an administrative circular issued by the Czech Ministry of National Defense imposing ecrtain conditions with respect to the hiring and firing of employees by firms engaged on government contracts. The Czech government pointed to its various legislative enactments, forbidding the insertion in government contracts of any conditions with respect to Czech race and in particular forbidding dismissal of any employee by reason of the fact that he was not of Czech race, and further declared that the Circular in question had never been made effective. On these representations, the Committee recommended that no action be taken. 18 O. J. 607-608 (1937).

${ }^{83}$ Several petitions involving this subject were presented to the League from minoritics in both Czechoslovakia and Rumania. In general in the case of the Czech complaints the pensions had been 
ship status, ${ }^{84}$ and confiscation of press facilities ${ }^{85}$ - to protests against agrarian reform legislation, ${ }^{86}$ denial of rights to establish schools and share in public funds devoted to educational purposes, ${ }^{87}$ or failure to implement the grant of political or religious autonomy ${ }^{88}$ as provided for in the treaties for certain groups. ${ }^{80}$

In general the major substantive difficulties encountered in the consideration of petitions related first, to the interpretation of the treaty provisions defining a minority; and second, to the implementation of the guarantee to minorities of equality of treatment in law and in fact. The minorities treaties defined a member of a minority group simply as a person "belonging to a racial, religious or linguistic

denied because claimant was not of the required nationality (I4 O. J. 465 (I935)) or was ineligible under the law by reason of his service in an enemy army (I5 id. II2I (I934) and C. 394. I929. I). In both cases the Committee recommended no action on the part of the Council. In the case of the Rumanian petition, the issue was one primarily of compensation for the expropriation of petitioners' property and the settlement of petitioners' claims for pensions. The Council took cognizance of the dispute and eventually stucceded in compelling Rumania to recognize its liability. I6 O. J. 453 (1935) and 18 id. 314 ( 1937 ).

"This was a continuing problem for the League despite the comparatively detailed provisions of the minorities guarantees and the peace treaties relating to this subject. The petition raised both factual and legal questions. The question was of considerable importance, since in many cases it was the determinative issue in the eligibility of the petitioner for minority protection. See, e.g., 5 O. J. 1309 (1924), 13 id. 185,961 (1932), and C. 517.1926 .1 .

${ }^{85}$ In two cases published in the Journal, the Committee concluded that the seizure and confiscation had been in accordance with the law which was adjudged to be non-discriminatory in application. I5 O. J. III9-1120 (1934), and 17 id. 518-519 (1936).

${ }^{80}$ Complaints of this nature were directed against agrarian reform legislation carried out by almost all the minority nations and formed one of the most difficult questions which the League had to consider; see e.g., petitions submitted by the Ukrainians against Lithuania, note 72 supra; by German minorities against Czechoslovakia, C. 568, M. 339. 1922. I, and C. 95, 1925. I; and by Hungarians against Rumania, 7 O. J. 1084-1087 (1926), 12 id. 2043-2044 (I93I), and I3 id. 1238-1239, 1738 (1932); and pp. 617, 618 infra.

${ }^{87} \mathrm{Sec}$ e.g., petition of Greek-Catholic Hungarians Committee against Czechoslovakia alleging deliberate Czech policy of denationalization, non-recognition of claimants' Hungarian nationality, and compulsory attendance at Ruthenian rather than Hungarian schools. C. 36I. 1923. I. Also German minority petition against Czechoslovakia for latter's failure to allocate equitable share of educational budget to German Academy of Music. C. 387 . 1926. I. Hungarian minority petition against Rumania alleging educational discrimination in Transylvania by reason of the Rumanian "Cultural Zone" policy, which was designed to remedy the scholastic inferiority of the Rumanian population in the area by bringing in additional teachers from outside the area, offering them higher salaries, and requiring that the teaching be done in the Rumanian language. I3 O. J. I57, Irog-rirg (1932), and I4 $^{\mathrm{id}}$. at 428 (1933). Jewish petition against Hungary protesting its "numerus clausus" education law requiring that university enrollments be accepted only from those of unimpeachable loyalty, that the number of students of different races and nationalities should be in proportion to the inhabitants, and that each race should be represented in a proportion of at least $9 /$ xo of its respective population. 7 O. J. I45 (r926).

${ }^{88}$ See, for example, numerous petitions submitted on behalf of the Ruthenians in Sub Carpathanian Russia alleging that Czechoslovakia was not fulfiling her obligations under the minorities treaties to grant the area full political autonomy. While the Council accepted jurisdiction of the issue, it showed extreme sympathy with the Czech position that the illiteracy of the Ruthenians and their lack of economic and administrative training made it impossible to grant the area full autonomy and that a period of education and training must occur before the population could accept its responsibilities. C. 49r. M. 354. I92I. I; C. 821 . M. 310. 1923. I; C. I90(a). 1924. I; C. 33I. M. 107. I924. I; C. 654. M. 2I7. I927 I; C. 2x M. I2. I93I. I. B.

Sec also, complaint submitted by minorities on Mt. Athos against Greece protesting against Greek assertions of right to supervise admission of foreigners to the territory. 13 O. J. 307-308 (1932).

${ }^{80}$ For more detailed summary of some of the substantive problems brought to the attention of the League, consult L. P. MaIR, The Protection of Mrnorities j6-220 (1928); Jacob Robinson and Others, Were thie Minorities Treaties a Failure I13-122 (I943); Azcarate, op. cit. supra note 22, at 6r-91. 
minority.' Wo While the League never laid down in express terms the affirmative criteria which it employed in interpreting this provision, it did rule that minority status was neither predicated on the domicile ${ }^{01}$ or origin ${ }^{02}$ of the minority nor on their numerical strength. ${ }^{03}$ Two other questions relating to minority identity were referred to the Permanent Court of International Justice for decision. In the first case, involving a dispute over the citizenship rights provisions in the Polish treaty, Poland denied the competence of the League on the ground that the persons involved were not Polish nationals and hence were not entitled to minority status. The Court ruled against the Polish claim, pointing out that certain of the rights guaranteed in the minorities treaties were expressly stated to be applicable to inhabitants and that Article $\mathrm{I} 2$ placing these rights under the League guarantee made no qualification as to nationality. Hence non-nationals, if members of a minority group, were entitled to petition the League for protection of those rights which were not expressly restricted to nationals. The second case arose under the provisions of the Upper Silesian Convention guaranteeing minorities the right to attend schools of their own selection. ${ }^{95}$ Poland claimed the right to deny recognition to registrations in minority schools emanating from persons who were not in fact members of the German minority. Germany contended, on the other hand, that membership in a minority was essentially a subjective matter and that a declaration of membership was sufficient to foreclose the question. In support of her contention, Germany cited Article 74 of the Convention which provided that "the question whether a person does or does not belong to a ... minority may not be verified or disputed by the authorities." The Permanent Court rejected the German argument, adopting the somewhat anomalous position that while the question of minority identity must be regarded as objective, the declaration of an individual as to his status could not be disputed. The Court then added that:

... it must not be inferred from this that the construction given above according to which the declaration must in principle be in conformity to the facts is therefore of no value. It is indeed of some importance to establish what is the situation at law.

Since the Court rendered its decision in the face of the express prohibition on verification, it would seem that under the general minorities treaties which contain no analogous prohibition, the criterion of minority status would be clearly regarded as objective in nature.

\footnotetext{
${ }^{\circ 0}$ See notes 31 and 47 supra.

${ }^{01}$ See claim of Germany protesting the receivability of a petition relating to Upper Silcsia on the ground that the petitioner was not connected with the plebescite area by any permanent ties and resided there only temporarily. 14 O. J. 840 (1933).

02 This claim was first raised by Lithuania in contesting the minority status of certain Ukrainians; see note 72 supra.

${ }^{03}$ See notes 72 and 92 supra.

os Acquisition of Polish Nationality, Ad. Op. No. 7, Sept. 15, I923, I Hudson 237.

${ }^{95}$ Rights of Minorities in Upper Silesia (Minority Schools), Judgment No. 12, April 26, 1928, 2 Hudson 268.
} 
Under the equality of treatment clauses, the Council was faced with an entirely different although equally important problem. Innumerable petitions were submitted by minority groups in all minority countries protesting against the discriminatory nature of agrarian reform legislation on the ground that it was directed solely at the expropriation of minority-held property. ${ }^{\theta 8}$ While the legislation on its face was written in general terms, there was no question that statistically it affected minority groups more severely than majority ones in view of the fact that in many of the countries a major part of the land was owned by members of the minorities, while a majority of the population were peasants. Yet to have attempted to label the legislation as contrary to the minorities treaties by reason of its application would have been to condemn all agrarian reform legislation, which was regarded by these governments as the key to the economic and social consolidation of their country. In general, the Council refused to sustain the petitions, after painstaking investigation to ensure that the legislation was in fact a product of a national economic policy and not designed simply to impoverish and weaken minority groups. A second difficulty encountered in this respect arose out of the minority provisions conferring equal educational opportunities on all minorities. The fundamental question as to what constituted equality of educational rights was presented most graphically by the Albanian action in suppressing all private schools irrespective of their ownership by minority or majority, ${ }^{97}$ thus confronting the League with the alternative of insisting on a privileged position for the minority or of permitting a state to deprive its minority groups of one of their chief means for the unhampered development of cultural and national consciousness. The question was submitted by the League to the Permanent Court for an advisory opinion. The Court ruled that despite the non-discriminatory character of the law, the legislation in fact deprived the minority of an institution essential to their existence and hence violated the minority treaty provisions guaranteeing equality of treatment in law and in fact. The Court pointed out that whereas equality in law precluded discrimination of any kind, equality in fact demanded the maintenance of an equilibrium between different situations and frequently would necessitate a different treatment for the minority in order to approximate the equality called for. In the instant case, in the Court's view, private schools constituted an essential organ for the satisfaction of the special needs of the minority. Hence their abolition by the state constituted an unfair discriminatory action in view of the fact that similar needs of the majority could be adequately supplied by governmental institutions.

Similar problems arose with respect to the traditional exercise by the state of control over the school program and curriculum of private schools-a control which

${ }^{\circ 0}$ Azcarate, op. cit. supra note 22, at 61-66. In I933 Germany sought to test the validity of the Polish agrarian reform legislation before the Permanent Court, but after the Court's denial of her request for an order to preserve status quo pending the outcome of the action, withdrew her case, to which Poland agreed. 3 Hudson 292.

${ }^{87}$ Minority Schools in Albania, Ad. Op. No. 64, April 6, 1935, 3 Hudson 484. 
was not expressly provided for in the treaties but which could be utilized indirectly by a state to vitiate the practical effect of the Permanent Court's ruling in favor of the minorities' right to regulate their own educational institutions. ${ }^{08}$ The League was never able to reconcile the conflicting interests involved. As Azcarate put it:00

When we attempted in a friendly manner to extract some concession from the government nothing was easier for the latter than to justify its refusal on the grounds not only of its being under no treaty obligation but also of the risk involved by the uncertain attitude of the minority. And if we tried to convince the minority of the necessity and desirability of collaborating loyally with their new state, they cited the intolerant attitude of the government as the cause of their unhappy state.

Despite the impossibility in these cases of reconciling the conflicting interests of both minority and majority in situations in which right apeared to be equally divided, the League was able to alleviate some ${ }^{100}$ of the more obvious injustices practiced against minority groups. With respect to agrarian reform legislation, where instances of actual discrimination could be proved, the League was able on several occasions ${ }^{\mathbf{1 0 1}}$ to obtain monetary compensation for the expropriated minority, although it seldom succeeded in securing restoration of the property. In other instances, League negotiations resulted in modification of the offending legislation. ${ }^{102}$ There can be no question that in countless other situations the very existence of the League machinery constituted a deterrent to the adoption of extreme anti-minority

${ }^{98}$ Azcarate, op. cit. supra note 22, at 77-8I. Azcarate points out that on the one hand, the state refused to deprive itself of this potent weapon to weld the diverse population elements to a unified whole politically or to relax a control which it feared would be seized upon, not necessarily by the minoritics themselves, but by a foreign state whose population was the same as the minority. On the other hand, to the minority, their schools were of value primarily as organs of minority culture. The rights they claimed to be entitled to under the minorities treaties were not simply to educate their children in their own language but also to teach in the form and spirit appropriate to their culture and national consciousness.

${ }^{90} \mathrm{Id}$. at $8 \mathrm{I}$.

${ }^{200}$ Least effective action on the part of the Council was taken with respect to those complaints alleging violence and repression meted out to minority groups. The delicacy of the political situation and the inadequacy of friendly pressure and persuasion vis-a-vis this type of governmental action accounted in part for League impotence in these matters. Azcarate, op. cit. supra note 22, at 66 et seq.

${ }^{101}$ After protest to the League by the Ukranian minority in Lithuania against a section of the Lithuanian land reform law which confiscated land formerly held by the Russian government, a new law was enacted providing for compensation of the expropriated landowners up to 50 percent of the land value and also for the eligibility of such persons for a share in the redistribution of the land. The new law was undoubtedly enacted as a result of League pressure. 11 O. J. 967-968 (1930). Similar concessions were secured as a result of League efforts with respect to Rumanian confiscations of Czeckler property in Transylvania. 7 O. J. $1084-1087$ (1926); 12 id. 2043-2044 (193I); 13 id. 1238-1239, 1738 (1932); 16 id. 453 (1935); 18 id. 314, 270-27I (1937). See also petition of Bulgarian Monastery on Mt. Athos against Greek failure to pay compensation agreed upon for expropriation. The Lcaguc was able to straighten out the dispute. II O. J. 829 (1930); 13 id. 155-156 (1932).

${ }^{202}$ See, for example, petition relating to Czech circular governing hiring and firing policics for industries working on government contracts. See note 82 supra. The Czech government in its reply, while denying the discriminatory nature indicated that the circular was not put into effect-a result which very probably was induced by the representations of the League. Also Hungarian protest against Rumanian educational policies with particular reference to the use of allegedly biased textbooks-as a result of League concern, certain of the offending textbooks were withdrawn. 13 0. J. 157, 1109-1 I 10 (I932); I4 id. 428 (1933). 
measures. While League difficulties in enforcing observance of minority rights were frequently unrelated to substantive defects in the drafting of minorities treaties, it would appear that many arguments employed by minority states to justify their recalcitrant position might have been avoided had the substantive provisions been specified in greater detail and with greater precision. ${ }^{103}$

During its operation from 1920 to 1939 , the minority system was subjected to constant criticism from both minority groups and minority states. The petition system was the most consistent target of this criticism. It was urged that a minority should be required to submit its complaints through its own government, in this way providing the latter with an opportunity of remedying the action complained of before League intervention, and at the same time encouraging a minority to look to its own state in the first instance for satisfaction of its grievances. ${ }^{104}$ While a majority of the League was unwilling to accept the proposal-apparently seeing it primarily as a means to restrict the operation of the system-it would seem that the reasons advanced in its support, constitute potential advantages outweighing the possible disadvantages of the device being used as a delaying tactic. A somewhat similar plan was successfully adopted in the Upper Silesian minority procedure by the institution of the local minorities offices to which petitions were submitted in the first instance. Moreover, the principle accords with the familiar concept of exhaustion of administrative remedies which has seldom caused undue hardship or injustice in municipal practice. A second objection to the minority system was its extension of the right to petition to non-minority groups, ${ }^{105}$ because of the abuse to which that right was subject in the hands of groups desiring to exploit the minority cause for their own purposes. The refusal of the League to adopt a modification of this aspect of the system would appear to be wholly justified. To have prohibited the right of petition to international organizations, for example, might have constituted a severe handicap to the less advanced minority groups who were either unaware of their international rights or too weak to advance their own cause. Moreover, protection against the type of abuse mentioned could, it would seem, be best secured through a strict enforcement of the proper conditions of receivability and a careful screening procedure for petitions, such as was performed by the Minorities Section and the Minorities Committees.

Proposals with respect to the petition system were not confined to those designed to restrict its scope. Several nations urged that the system was too restrictive of minority rights and that the role of the individual petitioner should be expanded to

\footnotetext{
${ }^{103}$ Azcarate disagrees with this position, preferring the greater flexibility which can be attained under more generalized provisions, and cites in support of his position the numerous difficulties which arose under the Upper Silesian Minority Convention despite its detailed substantive provisions. Azcarate, op. cit. supra note 22 , at $140-14 \mathrm{I}$. While flexibility is a desirable attribute, clarity of purpose must not be sacrificed on that account.

204 This was first proposed by Poland in 1923 , see note 62 supra. In 1929 the Canadian representative, M. Dandurand, made a similar recommendation to the Council during its $54^{\text {th }}$ Session. Protection of Linguistic, Racial or ReLigious Minorities, supta note 56 , at 87.

${ }^{105}$ See note 62 supra.
} 
approximate that of a party plaintiff with a legal right to bring his complaint personally before the Council and to present his own arguments. ${ }^{100}$ Underlying the proposal was a dissatisfaction with the temerity frequently displayed by the League in the face of obvious violations of the minorities treaties and a feeling that a right on the part of a complaining minority to present its case directly to the League would force the League into action. In part the dissatisfaction was due to a lack of publicity accorded to actual accomplishments of the League in the field of minority problems and a consequent feeling that nothing was being done. In part it stemmed from a belief that the system favored minority states over minority groups, since it provided no formal opportunity for the latter to present their side of the case. The proposal was met by the immediate objections of those who conceived of the role of the League not as a judicial tribunal but primarily as a supervisory body which sought by means of friendly pressure and informal negotiation to remedy the grievances complained of-an approach necessitated by the lack of sanctions other than moral suasion available to the League to compel a state to cooperate with its proceedings or comply with its decisions. While no fundamental objection is perceived to the guarantee of direct hearing rights to minority groups, ${ }^{107}$ there is no assurance that the existence of such a right would have resulted in any substantial improvement in the effectiveness of the League system or in the ability of the League to assure that respect for minority rights which the system was established to promote. There is little evidence available which indicates that the minority's view of the dispute was not fully known to the investigating committee or that it tended to favor the minority governments over minority groups. The major difficulties encountered by the League did not lie in its inability to assert the justice of a particular complaint but rather in its attempts to negotiate solutions for the problems which presented themselves ${ }^{108}$-difficulties which would appear to be largely unrelated to the nature of the hearing right provided.

Two other proposals directly related to this problem were also made to the League during this period; one, that greater publicity be accorded to League activity in the minorities field; ${ }^{109}$ and the other, that a permanent Minorities Commission

${ }^{100}$ This proposal was most vigorously supported by the Hungarian representatives. Sce particularly the debates in the 6th Committee at the 16 th and 17 th Sessions of the Assembly. O. J. Spec. Supp. Nos. I38 (I935) and I55 (I936). And in the Council: Protection of Linguistic, Rnial or Religious Minonities, supra note 56 , at 129 .

${ }_{107}$ Geneva Conv. Art. 149, stipra note 34. See also, Stone, op. cit. supra note 34 , at III-113.

108 The only case of outright refusal to supply information requested by the League involved the Lithuanian government. After considerable negotiation and discussion Lithuania eventually supplied the necessary data.

Azcarate declares that the greatest difficulties encountered by the League in its efforts to negotiate successful solutions to minorities problems arose not with regard to national policies but with respect to violations occasioned by the hostility of local authorities towards the minorities. Azcarate, op. cit. supra note 22 , at 45 .

${ }^{100}$ The question was repeatedly raised in the debates of the 6th Committee of the Assembly. Sce O. J. Spec. Supp. Nos. 99 (1931) and 109 (1932), and in the 54th Session of the Council. Protzcrion of Linguistic, Riacial or ReIigious Minorities, supra note 56, at 87-96. Increased publicity has been urged in Jacob Robinson and Others, Were the Minorities Treaties a Failure 107 (1943). For considerations of factors militating against too much publicity, see Azcarate, op. cit. supra note 22, at Ir 8-Irg. 
be established ${ }^{110}$ with independent investigatory and visitorial powers similar to the Mandates Commission. ${ }^{111}$ The question of publicity is difficult to resolve. Not all minorities disputes were of the nature calculated to arouse world opinion to act as moral pressure on the side called upon to make reasonable concession. Too much publicity accorded states the opportunity to justify their actions in terms of prestige and national security-arguments calculated to carry considerable appeal to all governments. Finally, because of the delicate nature of minorities work, carried on as it was in the midst of strongest political passions, and because of the reluctance of states to submit to international interference in what constituted "the most sensitive sphere of their political life,"112 compromises were difficult to work out if too much public light were thrown on their progress, especially in the face of a hostile public opinion at home. On the other hand, complete absence of publicity surrounding the great bulk of League activity was not calculated to arouse public confidence in its work. Much of the criticism raised against the League was due to ignorance of the types of problems involved and the accomplishments which were achieved. The solution no doubt lies somewhere between the two extremes so that the public can be kept informed of what is being done without jeopardizing the progress of minority negotiations.

The proposal for the creation of a permanent Minorities Commission would seem to have considerable merit. Such a body would have lessened League dependence on the petition system for information as to the existence of violation-a dependence which inevitably resulted in predicating international protection on the strength and organization of minority spokesmen rather than on a basis of need.

In addition to these proposals directed towards the amendment of specific procedural aspects of the minorities machinery, the Assembly debates reflected a deepseated dissatisfaction with regard to the operation of the system as a whole, which frequently stemmed from a fundamental disagreement both as to the efficacy of international supervision and as to the validity of the assumption that protection of group rights provided the key to the solution ${ }^{113}$ of the problem of intergroup frictions.

${ }^{210}$ Proposal advanced by the delegates from Canada, Albania, The Netherlands, and Germany at various League sessions. O. J. Spec. Supp. Nos. 64, pp. 37-38 (1928), No. 99, p. 15 (1931), No. 90, p. 19 (1930), and Protection of LINGUistic, RAcias oR ReLigious Minorities, supra note 56, at 89-91. It has been favorably commented upon by C. A. Macartney, National. States and National Minorities 42I (I934) and by Robert W. Seton-Watson, The Problem of Smali Nations and the European ANARCHY (1939).

${ }^{211}$ See Treaty of Versailles, Art. 22; for general treatise on the experience of the Mandates Commission, see Quinct Wright, Mandates Under the Lengue of Nations (1930).

112 Azcarate, op. cit. supra note 22, at 2\%.

${ }^{113}$ The Assembly debates clearly bring out the lack of fundamental agreement on the question of whether the system of minority protection embraced in the treaties was directed towards the perpetuation of a system of cultural pluralism or rather towards a gradual assimilation of minority groups. See, for example, the discussion at the 8th Ordinary Session of the Assembly O. J. Spec. Supp. 54 (1927); and at 54th Session of Council in March, 1929. Protection of Linguistic, Racial or Religious Minorities, supra note 56 , at 89 . 
On the one hand it was argued that a permanent solution for majority-minority frictions must ultimately depend on "internal evolution" through mutual agreement and good faith. Not only was external intervention and pressure incapable of taking the place of this normal method of development, the argument proceeded, but also the presence of the League system constituted an affirmative barrier in the way of such development since it tended to crystallize group consciousness and prevent their consolidation into the political life of the state. Moreover, it encouraged minority groups to look to third parties for the solution of their difficulties and thereby weakened their confidence in their own government. ${ }^{114}$ At the same time, the system afforded hostile elements-both states and other organizations-an opportunity to harass minority nations and exploit the system for their own purposes of propaganda and the like.115 Others opposed the system primarily because of its unequal application and contended that it should be either abandoned or generalized so as to be applicable to all states containing minority groups. ${ }^{110}$ Proposals were therefore put forward for the formulation of a general convention on the question of minority protection. ${ }^{117}$ Several states, however, opposed the system because of their conviction that the problem could be more harmoniously handled by the international guarantee of basic human rights to all persons, irrespective of membership in a minority or a majority group. ${ }^{118}$

On the other hand, it was argued that national feeling against minority groups was such as to render wholly inadequate normal channels of recourse available to the ordinary citizen and that international supervision was therefore essential. Rather than creating and solidifying group consciousness, the system offered the only means of protecting groups which already entertained a feeling of group identity-a protection which was essential if the cultural patterns of the dominant group were not to stamp out those held by less powerful entities. To attempt to meet this problem by a guarantee of basic rights to individuals would ignore the fundamental

${ }^{11}$ See arguments of Poland and Czechoslovakia discussed supra note 62.

${ }^{115}$ See note 114 supra. One example of this was the activity of the Macedonian National Committee, a terrorist and revolutionary organization with headquarters in Bulgaria and operating with at least tacit support of the Bulgarian government, which repeatedly submitted petitions protesting against Yugoslavian measures of oppression against its Macedonian minority. While the facts showed unmistakable violations of the Minorities Treaties, the League was placed in the position that if it made formal representations to the Yugoslavian government it would thereby be encouraging activities on the part of the Committee whose real objectives were political and unrelated to the interests of the minority whose cause it espoused. Azcarate, op. cit. supra note 22, at 50, 69-70. Macartney, on the other hand, declares that the system was water-tight for purposes of preventing a complaint which was mere propaganda from reaching the Council. In fact, the system presented, in his opinion, a more serious danger that a valid complaint would be dismissed as propaganda. C. A. Macartner, Nattonal States and Natronal MinoRities 373 (I934).

${ }^{116}$ Azcarate has declared that in his opinion this inequality by itself was responsible for a substantial part of the hostile reaction on the part of the minorities countries against the minorities system, which they considered to be a humiliating restriction by reason of its limited application to certain states. AzCARATE, op. cit. supra note 22 , at 56.

117 Proposals for the formulation of such a convention were first advanced by Lithuania. O. J. Spec. Supp. No. 39 (I925). The subject was debated in several subsequent sessions of the Assembly. O. J. Spec. Supp. No. 120 (1933) and id. No. 130 (1934).

${ }^{118}$ This was the position adopted by the delegates from Haiti, The Irish Frce Statc, Argentina, and Australia (O. J. Spec. Supp. No. 130 (1934)), and from Greece (id. No. r20 (1933)). 
purpose of the system, which was to enable certain groups to preserve their cultural identity. The importance of this aspect of minority protection was emphasized by Count Apponyi, the Hungarian delegate to the Assembly. Discussing the transfer to Rumania under the peace treaty of the territories of Upper Hungary and Transylvania, which he characterized as the "oldest established centers of Hungarian culture," Count Apponyi declared: ${ }^{119}$

These lands have been a home of Hungarian culture for many centuries and you will realize that even if they are lost to us politically we are anxious not to lose that wealth of culture that forms an integral part of the Magyar national patrimony.

The alleged inequality of the system was claimed to be justified by the special circumstances prevailing in the countries subjected to the minority system-circumstances created not solely by the presence in a country of different races or religions, but by the fact that a minority in one country was adjacent to a majority of its race, language, or religion in a neighboring country from whose territory it had been recently transferred. ${ }^{120}$ Moreover, any attempt to generalize the system, it was agreed, would be confronted with insurmountable difficulties by reason of the singularly complex social and political phenomena which constituted the minority problem. As Dr. Benes pointed out, "its nature is different in every country; it hangs upon the historic development of both the majority and minority peoples concerned and upon their general culture and their political, social and economic conditions." "121

Reconciliation of these conflicting viewpoints presents an impossible task. The shortcomings of the League system are undeniable. The system was unable in many cases to prevent outbursts of violence directed against minority groups. Nor was it able to instill in minority groups, particularly among the German minorities in Czechoslovakia and Poland, a sense of loyalty towards, and identification with, their new state. It cannot be denied, however, that in a limited sphere of cases the League was able to remedy at least a portion of the injustices practiced against minority groups. There is little indication that the existence of the League system operated per se to impede the harmonious adjustment of minority-majority relations. On the contrary, a former member of the League Minorities Section has stressed as perhaps the most significant contribution of the League system the fact that by drawing to itself the bulk of resentment engendered by both minority groups and minority states, it provided a release for tensions which might otherwise have manifested themselves in increased intergroup frictions. ${ }^{122}$ In any case, its limited success

\footnotetext{
${ }^{110}$ Statement made in the course of debate in 6th Committee during $5^{\text {th }}$ Session of Assembly, O. J. Spec. Supp. No. 23 (I924), p. 89.

${ }^{120}$ See, e.g., remarks of Anthony Eden, British delegate, in course of debate on this question in 6th Committee during the $15^{\text {th }}$ Session of Assembly. O. J. Spec. Supp. No. 130 (1934), p. 59; id. No. 39 (1925).

${ }_{101}$ Quoted by M. Massigli, French delegate, in 6th Committee during $5^{\text {th }}$ Session of Assembly. O. J. Spec. Supp. No. 130 (1934).

122 AzCARATE, op. cit. supra note 22, at 82.
} 
in winning concessions or compromises from reluctant states attests to the ability of an international body to command a measure of support and cooperation-even though lukewarm and under protest.

Whether the minorities system would have been more effective had it placed primary emphasis upon individual rather than group rights; whether the limited application of the system constituted an impediment to its operation; or whether minority groups would have met with less ill treatment had there been no international supervisory body, are questions whose answers must necessarily remain speculative. In part, they have been rendered moot by the recent developments in the United Nations in the broad field of human rights. The establishment of a subcommission on the prevention of discrimination and the protection of minority rights, ${ }^{123}$ despite its significant lack of progress during its two year existence, would seem to be indicative of a determination on the part of the United Nations that special protections should be accorded to minority groups beyond those accorded to the individual. ${ }^{124}$ If such a system of protection finally emerges, it is clear that it will be of general application. Difficulties of definition, which inevitably arise in any attempt to establish such a universal system, ${ }^{125}$ are apparently to be met by emphasizing as the chief characteristics of a minority, its existence as a well defined group clearly distinguishable from the rest of the population (objective criterion), and its desire for a measure of differential treatment (subjective criterion). ${ }^{126}$ While the definition stresses the element of will and thus avoids one of the problems encountered by the League, several ambiguities are immediately apparent. Thus the definition furnishes no indication as to the nature of the objective factors required to prove that the group in question is well defined-particularly whether residence of the group will be material in this respect or whether the use of similar dialects or the practice of similar religious services will suffice. Nor is it clear whether in indicating the intent of the group for a measure of differential treatment, a simple declaration on behalf of a single member will suffice or whether a formal group statement to the UN is envisaged. ${ }^{127}$ Also unanswered in the proposed definition is the time at

\footnotetext{
${ }^{293}$ The Sub-commission was established at the first session of the Human Rights Commission in r947 after considerable debate as to whether two bodies should be created as urged by the delegates from India and Russia or whether both discrimination and minority protection should be assigned to one commission. A brief history of the Sub-commission is contained in U.N. Doc. E/CN. $4 /$ sub./2/2, September, r947; also United Natjons YeArboox of HuMran Rights, t947 425 (I949).

${ }^{124}$ The representatives from the USSR have been particularly insistent that the U. $N$. consider the minorities question. See, for example, debate at the 5 th mecting of ECOSOC, $2 \mathrm{~d}$ sess. E/PV/5, pp. 49-50. However, the approval by the U. N. of the Genocide Convention would seem by itsclf to indicate the general concern which prevailed among all $U$. N. members for the protection of minorities. For text of convention, see Journal of the General Assembly, No. A/PV, 178, at 2-5a, Dec. 9, 1948. Note that the argument put forward by the United States in opposition to the inclusion in the Convention of a ban on cultural genocide was based on the reasoning that acts of this nature should be dealt with by separate treaties for the protection of minorities. ECOSOC Doc. No. E/623 at II-13. Jan. 30, I948.

${ }^{125}$ See pp. 602-603 supra.

${ }^{120}$ Report of Subcommittee on its first session, Nov. 24 , Dec. 6, 1947, U. N. Doc. E/CN. 4/52, Dec. 6, I947; and E/CN. 4/Sub. $2 / 38$, Dec. 5, 1947; see also similar definition discussed at its second session, in May, I949, U. N. Doc. E/CN. $4 /$ Sub. 2/69, June 2I, I949.

${ }^{227}$ A draft resolution presented to the Sub-commission at its second session indicated the considera-
} 
which such declarations must be made, specifically whether if once made it is subject to retraction, or, on the other hand, whether failure to make a declaration will forever foreclose the possibility of securing minority status. Despite these ambiguities, it would seem clear that the emphasis upon the subjective criterion would clearly eliminate "externally created" minorities from the reach of the system. Recourse by those persons against discriminatory treatment or denial of basic human rights would presumably have to be taken under the Covenant on Human Rights. In view of the diversity among minority group types, suggestion has been made that a further breakdown of minority groups be established to allow for a more flexible differentiation of rights according to group type. ${ }^{128}$ While no specific implementation of this suggestion has as yet been forthcoming, the proposal would seem to have considerable merit, providing the classification would not devolve simply into separate minority systems for each state containing minority groups. The only substantive rights proposed to date to be included in the "charter" have related to the use of the minority language in school and in the courts. ${ }^{129}$ It is not clear whether the substantive rights to be included will be confined simply to those designed to assure to minority groups the preservation of their cultural identity. Since presumably protection against discrimination and denial of basic freedoms would be available under the Human Rights Covenant, it would appear unwise and unnecessary to duplicate such protection in any minorities "charter." Procedural proposals have in general constituted little departure from the League system, ${ }^{130}$ except for the scope of the petition right, which is to be limited to members of the United Nations, specialized organs, and non-governmental organizations. ${ }^{131}$ In view of the accreditation requirements with respect to organizations desiring to secure non-governmental organization status under the UN charter, ${ }^{132}$ it would appear that a greater measure of control over petitioning organizations will be available which may provide a salutary weapon in the hands of the UN against abuse of the petition right by such organizations. However, no comparable safeguards exist against similar abuse by member states. Moreover, the failure to date to provide for initial investigatory powers in some permanent body leaves the UN again dependent, as was the League,

tions on which effective protection must be predicated and that some type of formal demand for protection was intended. E/CN. $4 /$ Sub. $2 / 69$, June $2 \mathrm{I}, \mathrm{I} 949$.

${ }^{128} \mathrm{Ibid}$.

${ }^{220} \mathrm{E} / \mathrm{CN} .4 /$ Sub. 2/60, June 20, r 949.

${ }^{130}$ Summary of proposals presented to second session of Sub-commission in 20 Dep'T State Bulr. $8 \times 2$ (x949); also U. N. Doc. E/CN. $4 /$ Sub. 2/44, June 14,$1949 ; \mathrm{E} / \mathrm{CN} .4 / 45$, June 14, I949, E/CN. 4/49, June 15 , I949.

131 Ibid.

${ }^{133}$ Art. 71 of the U. N. Charter provides that the Economic and Social Council may make suitable arrangements for consultation with non-governmental organizations which are concerned with matters within its competence. Such arrangements may be made with organizations after consultation with the member of the United Nations concerned. Pursuant to this provision a Committee on Arrangements for Consultation with Non-Governmental Organizations was established by ECOSOC to work out accreditation requirements. This Committee considers all applications for NGO stanus, which must be finally approved by the ECOSOC. U. N. Doc. E/C. $2 / 98$. 
on the initiative of member states and organizations for information on the existence of violations of minority rights. Today's split between east and west has furnished sufficient examples of the willingness of nations to use Charter violations as a vehicle for. propaganda to warrant serious consideration for the establishment of machinery which places least reliance on, or furnishes least opportunity for, this type of activity. Finally, the system as it is taking shape would appear to offer no greater guarantee than the League in assuring states protection against the unwillingness of minority groups to identify themselves loyally with the over-all political goals of the state. Nevertheless, despite these shortcomings, on the basis of the proposals submitted to date, it would appear that the UN system for the protection of minorities if it finally emerges will have two major advantages over the League experiment. In the first place, by reason of its universal application and non-compulsory character, it should engender a more cooperative attitude on the part of those states which signify their willingness to adhere to the system. Moreover, its emphasis upon the desire of the group for differential treatment coupled with the availability under the Covenant on Human Rights of protection against discrimination and denial of basic freedoms should remove any incentive on the part of a group to maintain its group characteristics solely in order to claim the benefits of international protection as a national minority.

In the last analysis, the success of the system will depend not on the specific machinery adopted but rather on the spirit in which it is executed. The ultimate solution for intergroup frictions must rest on the development of mutual good will and respect as well as on a spirit of tolerance and appreciation for differences on the part of both minority and majority. The success of any international system of protection, whether of individual or of group rights, will be directly related to the extent to which the United Nations proves itself able to create and strengthen these attitudes among its member nations. 